\title{
The paragenesis of silver minerals in the Pb-Zn Stan Terg deposit, Kosovo: an example of precious metal epithermal mineralization
}

\author{
Joanna Kołodziejczyk ${ }^{1}$, Jaroslav Pršek ${ }^{1}$, Burim Asllani ${ }^{2}$, Feriz Maliqi ${ }^{3}$ \\ ${ }^{1}$ AGH University of Science and Technology, Faculty of Geology, Geophysics and Environmental \\ Protection, Department of Economic Geology; al. A. Mickiewicza 30, 30-059 Krakow, Poland \\ ${ }^{2}$ E\&E Experts LLC, 10000, Prishtina, Republic of Kosovo \\ ${ }^{3}$ Trepça - Enterprise under AKP Administration, Parku Industrial Mitrovicë, Mitrovicë, 40000, Republic of Kosovo
}

(C) 2016 Authors. This is an open access publication, which can be used, distributed and reproduced in any medium according to the Creative Commons CC-BY 4.0 License requiring that the original work has been properly cited.

Received: 9 February 2016; accepted: 12 April 2016

\begin{abstract}
This study reports silver mineral association found recently in the Stan Terg lead and zinc mine, located in the Vardar zone (in northern Kosovo). The described mineralization comprises pyrargyrite $\left(\mathrm{Ag}_{3} \mathrm{SbS}_{3}\right)$, frei-

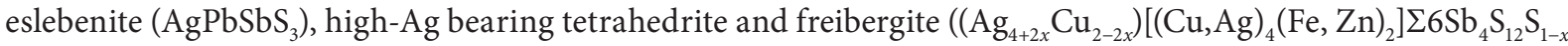
with $(0<x<1)$ ); as well as native compounds (Electrum, composition of those minerals was confirmed by the electron microprobe. The freibergite from native silver is native antimony). The Ag-minerals occur in vuggs and cracks in a massive galena ore and have signs of the latest minerals, which precipitated in the deposit. The chemical of the Stan Terg deposit reveals zonality and contains between 13.91-20.28\% of Ag. The high concentration of $\mathrm{Ag}$ in solutions is also indicated by relatively high silver content in Au-Ag alloy (electrum), which is between $47.02 \%$ and $73.19 \%$ of Ag. The Ag association is supposed to be an epithermal equivalent of precious metal mineralization, which could be located in the external part of the Stan Terg hydrothermal system. This association occurs in low temperatures, below $200^{\circ} \mathrm{C}$. The Ag-minerals can be a part of epithermal veins from the external part of the Stan Terg hydrothermal system. Similarly to the other known Pb-Zn-Ag hydrothermal systems, the Ag association is related to the formation of the rhodochrosite banded ore and $\mathrm{Ag}-\mathrm{Au}-\mathrm{Sb}$ dominated mineralization.
\end{abstract}

Keywords: Ag-minerals, pyrargyrite, freieslebenite, freibergite, Kosovo, Trepça mineral belt, Vardar zone

\section{INTRODUCTION}

Silver minerals are common ore minerals in various types of ore mineralizations and deposits primarily in epithermal vein systems, but they can be found also in skarn-, sedimentary-exhalative-, sediment-hosted-, porphyry-types of mineralization (e.g. Pearson et al. 1988, Grossou-Valta et al. 1990, Püttmann et al. 1991, Höller \& Gandhi 1995, Schalamuk et al. 1997, Zeng et al. 2000, Cheilletz et al. 2002, Shalaby et al. 2004, Seifert \& Sandmann 2006). Silver in the ore deposits occurs primarily in solid solutions with galena in the form of
$\mathrm{Bi}(\mathrm{Sb})+\mathrm{Ag}$ vs $2 \mathrm{~Pb}$ substitution (lillianite type). In high temperature conditions, silver could form various groups of $\mathrm{Ag}-\mathrm{Pb}-\mathrm{Bi}(\mathrm{Sb})$ sulphosalts. In epithermal mineralization, silver commonly forms its own sulphide minerals; e.g. pyrargyrite, stephanite, proustite, argentite and/or native silver.

Stan Terg is one of numerous $\mathrm{Pb}-\mathrm{Zn}$ deposits in the Vardar zone, located in the central part of the Balkan Peninsula (Southern Europe). In ancient times, mineral occurrences in the Balkan Peninsula were the main sources of $\mathrm{Au}$ and $\mathrm{Ag}$. Mineralization is associated with Tertiary volcanism and is related to hydrothermal activity. Silver 
mineralization is known from different base metal vein districts and deposits, for example the Podrinje Metallogenic District (Bosnia and Herzegovina), mainly from Srebrenica, where Ag-bearing tetrahedrite, stephanite, polybasite, pyrargyrite, argyrodite and native silver have been described (Radosavljević et al. 2016). The Zletovo mining district (Macedonia), freibergite, proustite, and pyrargyrite were described in sulphosalts paragenesis (Serafimovski et al. 2006). In the territory of Kosovo, pyrargyrite was reported by Smejkal (1960), and Smejkal \& Rakić (1957), in the Stan Terg, Hajvalia, Kizhnica and Kopaonik deposits. Berjaktarevic (1995) described the "Glama silver" prospect, near Gjilan, with a base metal ore with increased $\mathrm{Ag}$, Au and Sn contents.

Silver in the Stan Terg deposit is linked mostly with galena ore, as isomorphous substitution in a lattice with Bi (Kołodziejczyk 2012), as well as in the form of its own minerals (Smejkal \& Rakić 1957, Smejkal, 1960, Kołodziejczyk 2012). The Ag content in ore from the Stan Terg mine is $70 \mathrm{~g} / \mathrm{Mg}$ on average, with $\mathrm{Pb}+\mathrm{Zn}$ content around 10\% (Féraud \& Deshamps 2009, Trepça Mining Company internal documents). According to these works, most of the silver is linked to galena, and a minor part of it may belong to separate Ag-associations.

The purpose of this study is to report the electron microprobe data of the epithermal, Ag-bearing mineral association from Stan Terg in the external part of the deposit. This association may indicate the presence of an epithermal stage of evolution in the Stan Terg hydrothermal system.

\section{GEOLOGICAL SETTING}

The Stan Terg deposits and its hydrothermal system are located in Kosovo, within the Šumadija-Kopaonik ore district, known also as the Trepça mineral belt. It is a central part of the Vardar zone, in the vicinity of the Kopaonik granite massive (Hyseni et al. 2010). Stan Terg is the main Pb-Zn deposit, surrounded by numerous smaller occurrences, of the same hydrothermal origin (Fig. 1).

The major lithologies in the area are fragments of Paleozoic crystalline schists and phyllites, with unconformable overlying Triassic sediments, phyllites, volcanoclastic rocks and Upper Triassic carbonates. In the broad surrounding of the deposit, ultrabasic rocks and serpentinites of Jurrasic age are exposed on the surface. In addition a Cretaceous complex occurs with carbonates, clastics, serpentinite, volcanics and volcanoclastic rocks of basaltic composition. Tertiary (Oligocene-Miocene) volcanics of andesite, trachyte and latite composition are common in the area, and the surface is covered by felsic pyroclastic rocks (Hyseni et al. 2010, Strmić Palinkaš et al. 2013).

Mineralization in the Stan Terg deposit is generally hosted in the Mesozoic carbonates, at the contact with schists and the volcanic rocks of calc-alkaline affinity (Hyseni et al. 2010). The orebodies have an elongated shape of long mantos, or huge veins (with diameters up to few hundreds of meters). The orebodies stretch parallel to the conduit as columns. They split and join together in a form of a huge stockwerk.

The Stan Terg deposit has a large hydrothermal system with various mineralization styles, such as skarns, skarn-free carbonate-replacements, veins and breccias (Féraud \& Deshamps 2009, Hyseni et al. 2010, Strmić Palinkaš et al. 2013). Skarn minerals are observed primarily close to the central part of the deposit. According to Dangić (1993), part of the ore mineralization could occur during skarn formation; mainly magnetite, pyrite, pyrrhotite, chalcopyrite, sphalerite and galena. The skarns at Stan Terg are of Ca-type and consists of typical contact-metamorphic assemblages, with garnet, hedenbergite, ilvaite and actinolite. Within the skarn mineralization, Bi minerals were identified (Kołodziejczyk et al. 2015). The Bi-assemblage is also related to breccia mineralization, close to the central volcanic rocks. The main mineralization at Stan Terg was formed during the hydrothermal stage and comprises several generations of pyrite, galena, sphalerite, chalcopyrite, arsenopyrite, marcasite and lead-antimony sulfosalts (Féraud \& Deshamps 2009). The gangue minerals are various $\mathrm{Ca}-\mathrm{Mn}-\mathrm{Fe}-\mathrm{Mg}$ carbonates and quartz. Small veins and veinlets which run offset from the main orebodies are observed in the external part of the deposit. The hydrothermal phase was divided into four sub-stages: " $\mathrm{Zn}+\mathrm{Pb}$ " stage I, "Cu" stage II, "Ag" stage III and "Sb" stage IV (Kołodziejczyk 2012), where galena and sphalerite precipitated mostly during the first stage. According to this classification, Ag-mineralization is postponed only by the "Sb" stage comprising of boulangerite and heteromorphite. 


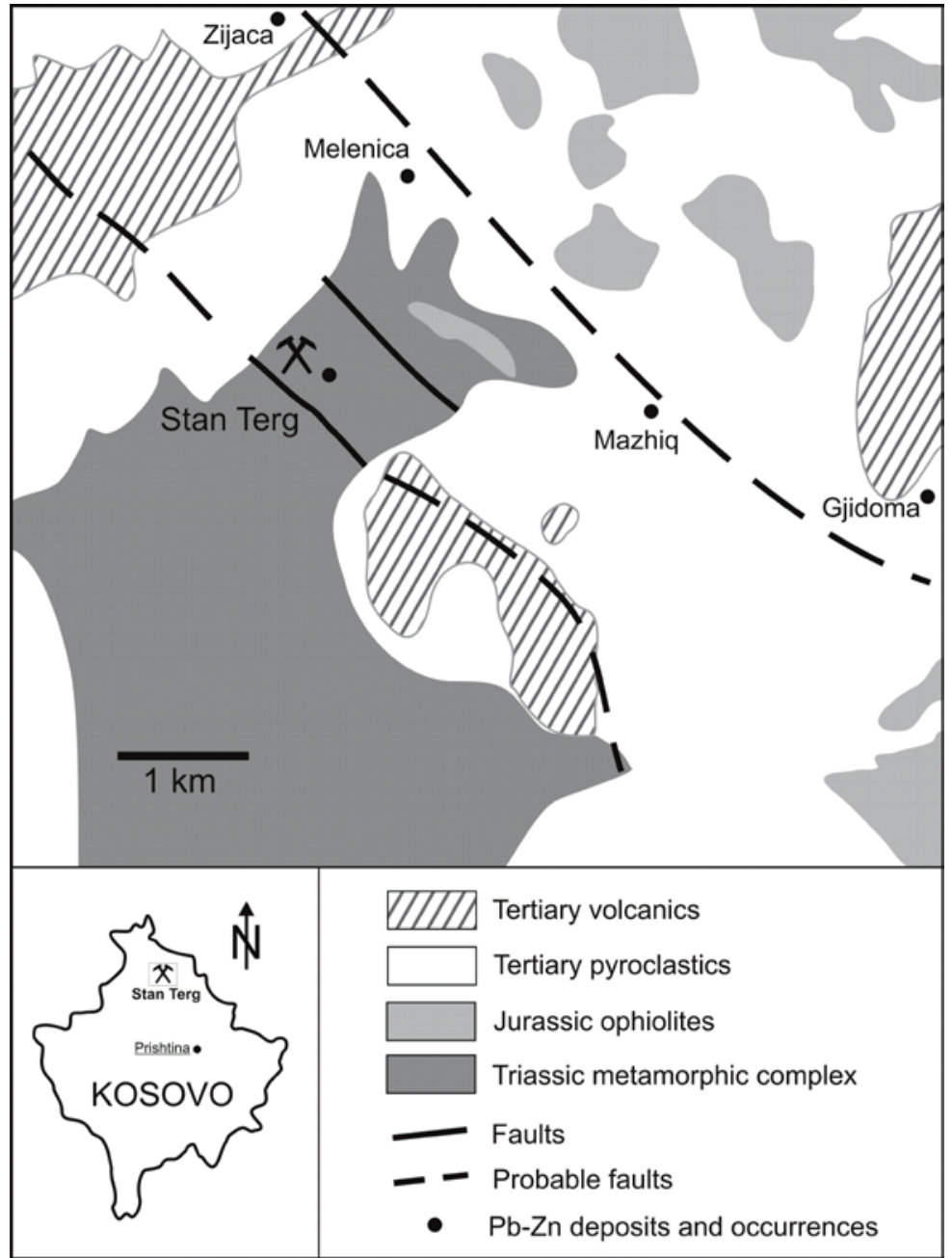

Fig. 1. Location and geological setting of the Stan Terg deposit (Kołodziejczyk et al. 2015)

\section{ANALYTICAL METHODS}

Silver minerals were found in samples collected from the central part of $149 \mathrm{e}$ orebody. This orebody is localized in the external, northern part of the deposit. All of the described phases were found in massive, fine-grained galena hand specimens, with minor pyrite and siderite in the vuggs.

Polished sections were examined by optical microscopy, and the chemical composition of the minerals was determined by a JEOL JXA- 8230 Super Probe electron microprobe in the Critical Elements Laboratory at the Faculty of Geology, Geophysics and Environmental Protection, AGH University of Science and Technology in Krakow.

The operating conditions for Ag-sulphosalts and native elements were as follows: accelerating voltage $20 \mathrm{kV}$, current $10 \mathrm{nA}$, peak time $10 \mathrm{~s}$, background time $5 \mathrm{~s}$, beam diameter was $3 \mu \mathrm{m}$. The following wavelengths were used: TeL $\alpha, \mathrm{SK} \alpha, \mathrm{PbM} \alpha$, CuKa, BiMa, AgLa, SbLa, SeLa, AsLa. Natural mineral standards $\left(\mathrm{PbS}, \mathrm{FeS}_{2}\right)$ and synthetic compounds $\left(\mathrm{Bi}_{2} \mathrm{Te}_{3}, \mathrm{Cu}, \mathrm{Ag}, \mathrm{Sb}, \mathrm{Se}, \mathrm{In} \mathrm{As}\right)$ were used for the calibration.

For freieslebenite and tetrahedrite, operating conditions were: accelerating voltage $20 \mathrm{kV}$, beam current $20 \mathrm{nA}$, peak time $20 \mathrm{~s}$, background time $10 \mathrm{~s}$ and a beam diameter between 0 and $5 \mu \mathrm{m}$. The following wavelengths were used: $\mathrm{PbMa}$, TeLa, BiMa, SbLa, Sela, CdLa, InLa, ZnKa, CuKa, SKa, SnLa, HgMa, FeKa, MnKa, AgLa, GaLa, GeLa, AsLa. Natural mineral standards (PbS, $\mathrm{ZnS}, \mathrm{FeS}_{2}, \mathrm{Sb}_{2} \mathrm{~S}_{3}, \mathrm{MnS}$ ) and synthetic compounds (InAs, $\mathrm{Cu}, \mathrm{Bi}, \mathrm{CdS}, \mathrm{PbTe}, \mathrm{Ag}, \mathrm{HgTe}, \mathrm{SnS}$, $\mathrm{Se}, \mathrm{Ga}$ ) were used for the calibration. 


\section{RESULTS}

The ore character of the $149 \mathrm{e}$ orebody is a little bit different from ore bodies in different parts of the deposit. The main ore mineral is a finely crystallized galena, with numerous microscopic boulangerite inclusions. Macroscopically visible crystals of boulangerite are rare. The minor minerals in the ore body are pyrite and pyrrhotite, and they occur especially at the contact with the host rocks. Sphalerite occurs in minor quantities, together with chalcopyrite and usually is observed only by using a microscope. The ore in this paragenesis is massive, with fine vuggs filled up by siderite and, less commonly, quartz. Galena has various textures, ranging from very fine (pure galena ore) up
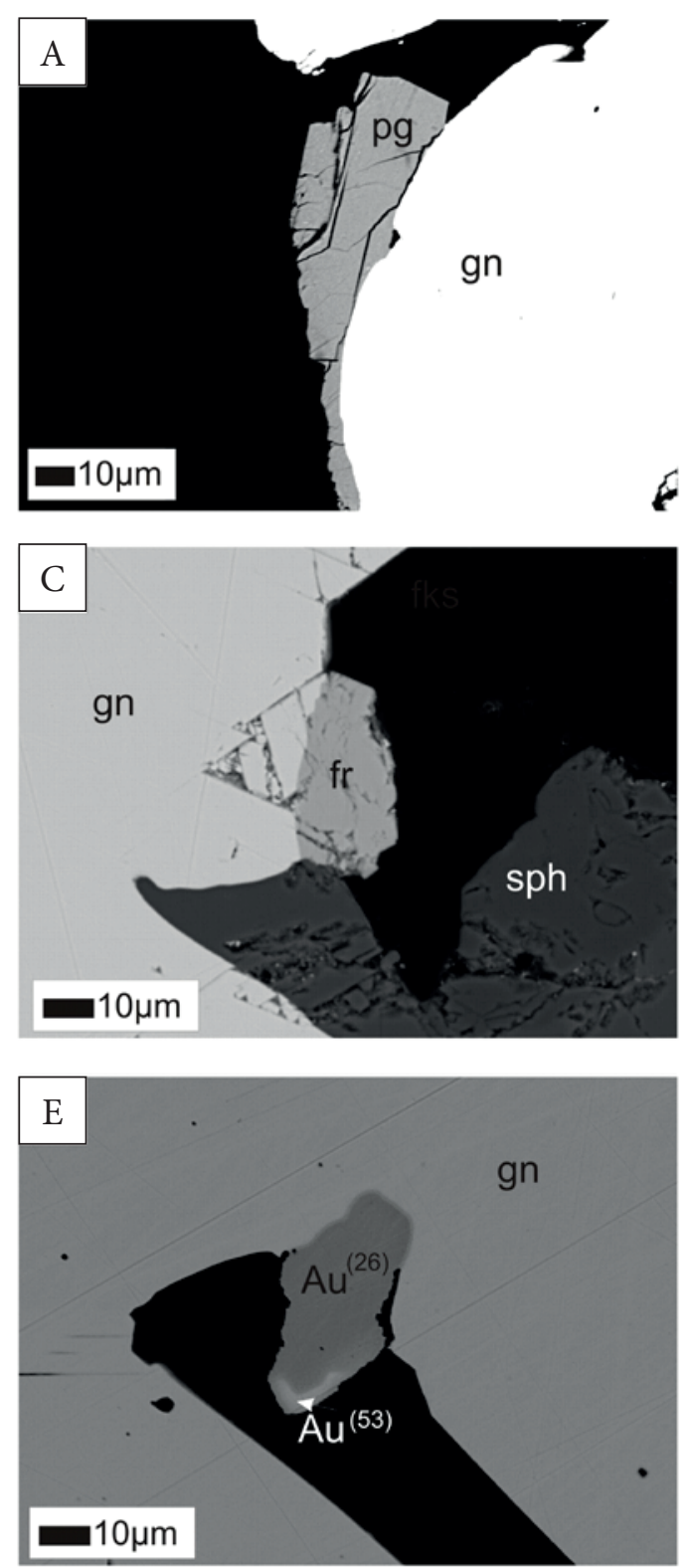
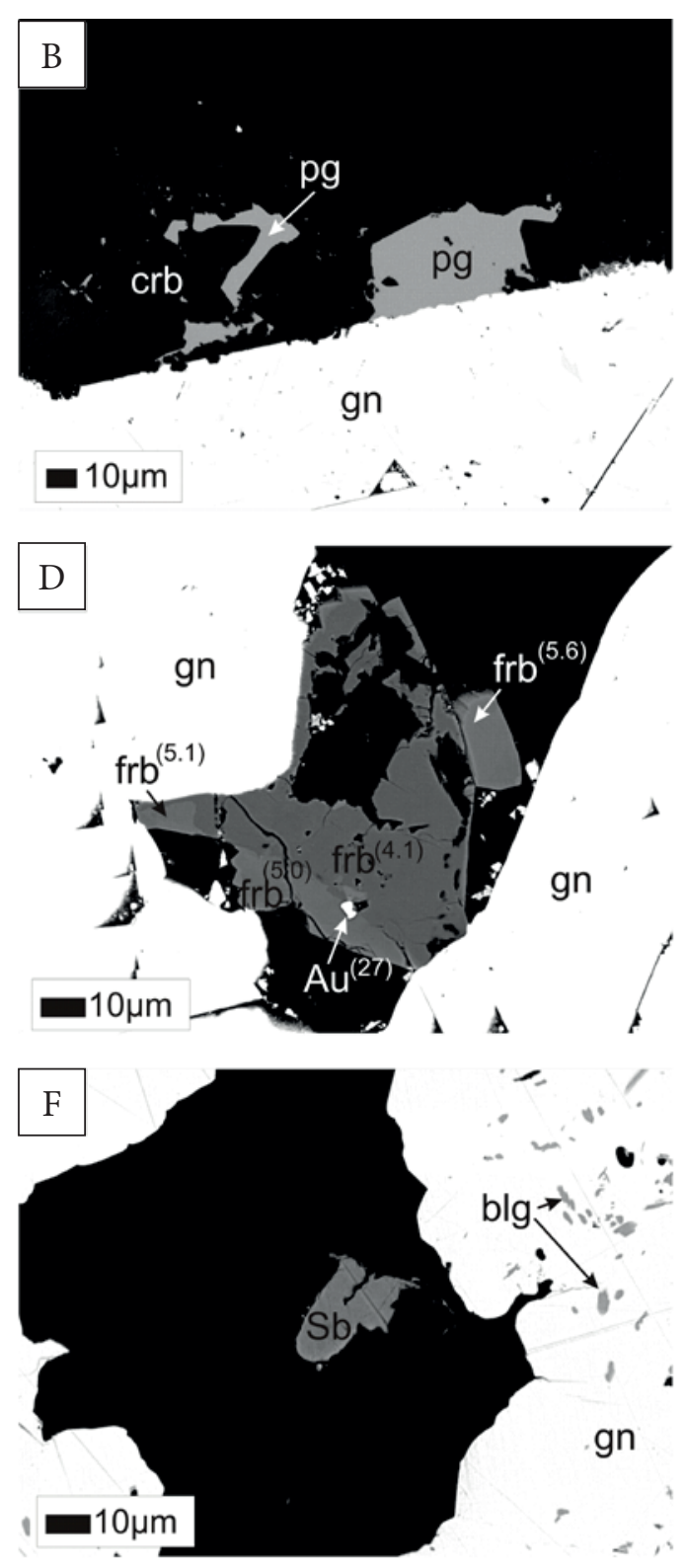

Fig. 2. BSE images of silver minerals from Ag-association at the Stan Terg deposit: A) pyrargyrite (pg) grains overgrown on galena ( $g n) ; B)$ pyrargyrite (pg) grains overgrown on carbonates and galena ( $g n)$; C) freieslebenite (fr) crystal overgrown on galena $(g n)$, sph - sphalerite; D) zonal freibergite (frb) and electrum grain (Au) in the vugg in galena ( $g n)$; E) zonal electrum crystal (Au) overgrowing galena ( $g n)$; numbers in bracket indicate Au content in atomic \%; F) native antimony (Sb) grain in a vugg, blg - boulangerite; numbers in brackets indicate Ag content (apfu) in freibergite, and Au content in atomic \% in electrum 
to coarse-grained (as mixture with other ore minerals in the contact zone).

The Ag minerals seem to be the youngest phases in the ore paragenesis. They occur usually as free, rounded crystals overgrowing galena, or they fill the fine cracks or vuggs in the ore (Fig. 2A-F). Paragenetic observations suggest that pyrargyrite and pyrostilpnite are younger than chalcopyrite and tetrahedrite. The position of native elements with other Ag minerals is still questionable, because they are not occurring together.

Back-scattered electron images (BSE) provided information about the zonality of the analyzed phases, observed mainly in tetrahedrite and electrum phases.

\section{Pyrargyrite/pyrostilpnite}

Pyrargyrite is the most abundant Ag mineral in the described association. It occurs as separate grains, overgrowing galena in the vuggs, or replacing chalcopyrite and tetrahedrite. No zonation is observed in these crystals (Fig 2A, B).

Microscope observations indicate the presence of different colours of internal reflections in the phases corresponding to $\mathrm{Ag}_{3} \mathrm{SbS}_{3}$ composition. According to Uytenbogaardt \& Burke (1985), this phenomenon may separate pyrargyrite from pyrostilpnite that may be distinguished with red or brownish internal reflections, respectively. Hence, we can conclude that in the Stan Terg deposit both phases occur, as a result of the internal reflections of both colours.

The chemical composition of measured grains is close to the ideal $\mathrm{Ag}_{3.02} \mathrm{Sb}_{0.98} \mathrm{~S}_{3.00}$, and is presented in Table 1, and plotted on diagram (Fig. 3). No arsenic was detected, and there is no sign of the presence of a pyrargyrite-proustite solid solution.

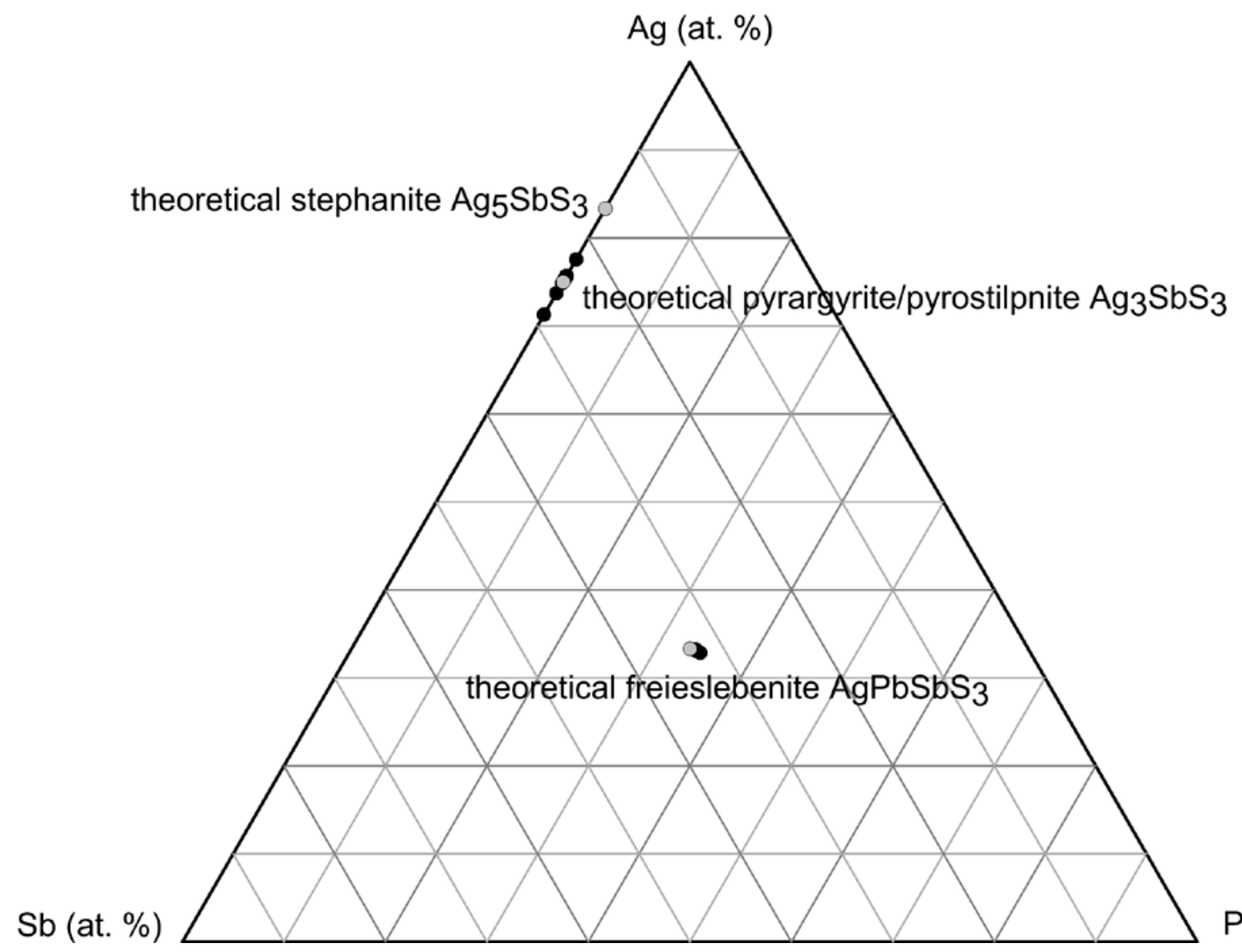

$\mathrm{Pb}($ at. \%)

Fig. 3. Ag-Sb-Pb tertiary plot (at. \%) for Ag-minerals from the Stan Terg deposit 
Table 1

Chemical composition of pyrargyrite (1-3) and freieslebenite (4-6) from the Ag-association at the Stan Terg deposit (wt. \%); b.d. - below detection limits, n.a. - not analyzed

\begin{tabular}{|c|c|c|c|c|c|c|}
\hline & 1 & 2 & 3 & 4 & 5 & 6 \\
\hline $\mathrm{Pb}$ & 0.07 & b.d. & b.d. & 39.75 & 39.33 & 39.81 \\
\hline $\mathrm{Fe}$ & n.a. & n.a. & n.a. & 0.43 & 0.99 & 1.08 \\
\hline $\mathrm{Cu}$ & 0.04 & 0.02 & b.d. & b.d. & 0.02 & 0.07 \\
\hline $\mathrm{Ag}$ & 59.69 & 59.52 & 59.54 & 19.69 & 20.04 & 20.03 \\
\hline $\mathrm{Sb}$ & 22.03 & 21.88 & 21.65 & 22.02 & 22.33 & 22.46 \\
\hline $\mathrm{Bi}$ & 0.11 & 0.01 & 0.09 & 0.02 & 0.14 & 0.09 \\
\hline $\mathrm{Te}$ & b.d. & b.d. & b.d. & 0.06 & b.d. & 0.02 \\
\hline$S$ & 17.68 & 17.60 & 17.61 & 18.08 & 18.13 & 18.07 \\
\hline Total & 99.62 & 99.03 & 98.89 & 100.05 & 100.98 & 101.63 \\
\hline \multicolumn{7}{|c|}{ Chemical formula* $^{*}$} \\
\hline $\mathrm{Pb}$ & 0.00 & b.d. & b.d. & 1.02 & 0.99 & 0.99 \\
\hline $\mathrm{Fe}$ & - & - & - & 0.04 & 0.09 & 0.10 \\
\hline $\mathrm{Cu}$ & 0.00 & 0.00 & b.d. & b.d. & 0.00 & 0.01 \\
\hline $\mathrm{Ag}$ & 3.01 & 3.02 & 3.02 & 0.97 & 0.96 & 0.95 \\
\hline $\mathrm{Sb}$ & 0.98 & 0.98 & 0.97 & 0.96 & 0.95 & 0.95 \\
\hline $\mathrm{Bi}$ & 0.00 & 0.00 & 0.00 & 0.00 & 0.00 & 0.00 \\
\hline $\mathrm{Te}$ & b.d. & b.d. & b.d. & 0.00 & b.d. & 0.00 \\
\hline$S$ & 3.00 & 3.00 & 3.01 & 3.00 & 2.94 & 2.90 \\
\hline
\end{tabular}

* Chemical formula based on 4 cations for pyrargyrite and 4 cations for freieslebenite.

\section{Fereieslebenite}

Freieslebenite is rare and occurs similarly as the pyrargite, overgrowing galena. Single grains are up to $20 \mu \mathrm{m}$ and reveal no zonation (Fig. 2C). The chemical composition is close to the ideal, $\mathrm{AgPbSbS}_{3}$. Representative analyses are presented in Table 1 and are plotted on the diagram (Fig. 3). No As was detected in the analyses.

\section{Ag-rich tetrahedrite and freibergite}

The status of freibergite as a separate mineral is discussed. Moëlo et al. (2008) summarized reports concerning Ag-rich tetrahedrite and freibergite. Following Rozhdestvenskaya et al. (1993) the actual structural formula of freibergite may be represented as $\left(\mathrm{Ag}_{4+2 x} \mathrm{Cu}_{2-2 x}\right)\left[(\mathrm{Cu}, \mathrm{Ag})_{4}(\mathrm{Fe}, \mathrm{Zn})_{2}\right]$ $\Sigma 6 \mathrm{Sb}_{4} \mathrm{~S}_{12} \mathrm{~S}_{1-x}$ with $(0<x<1)$. Hence, the Ag content in freibergite is between 4-6 apfu (atoms per formula unit). The phases with Ag below 4 apfu should be called Ag-rich tetrahedrite.

Tetrahedrite group minerals found together with Ag phases are represented by Ag-rich tetrahedrite and freibergite. Representative chemical analyses of these minerals are presented in $\mathrm{Ta}$ ble 2. The minimal Ag content in Ag-rich tetrahedrite is $10.65 \%$, what corresponds to $3.09 \mathrm{apfu}$.
In freibergite from Stan Terg, the Ag content varies between 13.91-20.28\% (4.02-5.68 apfu) and the $x$ value varies between 0.01 and 0.84 . There is a strong correlation between $\mathrm{Ag}$ and $\mathrm{Cu}$ content (Fig. 4A). The freibergite shows zonality in the BSE images which is due to differentiated Ag content (Fig. 2D). The Fe and Zn contents are variable and do not depend on $\mathrm{Ag}$ content. Most of the results indicate $6 \%$ of $\mathrm{Fe}$ and $1 \%$ of $\mathrm{Zn}$, what corresponds to about $1.7 \mathrm{Fe}$ apfu, and $0.3 \mathrm{Zn}$ apfu (Fig. 4B). The Ag-rich tetrahedrite and freibergite from Stan Terg contain up to $0.03 \mathrm{apfu}$ of $\mathrm{Pb}$.

\section{Native elements}

Numerous minute grains of electrum have been found in the described Ag-association. The electrum occurs as separate, rounded grains overgrown on galena, or within freibergite. The maximum dimension of the electrum is up to $20 \mu \mathrm{m}$. Chemical analyses of the electrum show variable $\mathrm{Au}$ vs Ag contents (Tab. 3). The electrum from the Stan Terg mine is characterized by a high content of Ag, which at its maximum could reach $73.19 \%$. Practically all analyses are silver dominant, which indicates the presence of Ag-rich solutions. 
Table 2

Chemical composition of Ag-rich tetrahedrite (1-4) and freibergite (5-7) from the Ag-association at the Stan Terg deposit (wt. \%); b.d. - below detection limit

\begin{tabular}{|c|c|c|c|c|c|c|c|}
\hline & 1 & 2 & 3 & 4 & 5 & 6 & 7 \\
\hline$S$ & 22.53 & 22.69 & 22.43 & 22.41 & 21.21 & 21.56 & 20.73 \\
\hline $\mathrm{Ag}$ & 20.86 & 21.23 & 22.00 & 23.54 & 27.04 & 27.15 & 32.78 \\
\hline $\mathrm{Cu}$ & 22.02 & 21.31 & 20.81 & 20.72 & 17.44 & 17.96 & 14.45 \\
\hline $\mathrm{Fe}$ & 1.53 & 0.54 & 7.15 & 6.50 & 8.25 & 5.33 & 5.26 \\
\hline $\mathrm{Sb}$ & 26.33 & 26.37 & 26.18 & 26.80 & 26.41 & 26.04 & 25.68 \\
\hline $\mathrm{Zn}$ & 7.42 & 6.34 & 1.66 & 0.44 & b.d. & 0.73 & 0.99 \\
\hline $\mathrm{Pb}$ & 0.18 & b.d. & b.d. & 0.17 & 0.06 & 0.08 & 0.12 \\
\hline Total & 100.87 & 98.48 & 100.23 & 100.58 & 100.41 & 98.85 & 100.01 \\
\hline \multicolumn{8}{|c|}{ Chemical formula on the basis of 16 cations } \\
\hline $\mathrm{S}$ & 12.45 & 13.14 & 12.36 & 12.51 & 11.83 & 12.56 & 12.09 \\
\hline $\mathrm{Ag}$ & 3.42 & 3.66 & 3.60 & 3.91 & 4.48 & 4.68 & 5.68 \\
\hline $\mathrm{Cu}$ & 6.24 & 6.33 & 5.88 & 5.93 & 4.99 & 5.34 & 4.32 \\
\hline $\mathrm{Fe}$ & 0.48 & 0.18 & 2.26 & 2.08 & 2.64 & 1.78 & 1.76 \\
\hline $\mathrm{Sb}$ & 3.83 & 4.02 & 3.80 & 3.94 & 3.88 & 3.98 & 3.94 \\
\hline $\mathrm{Zn}$ & 2.01 & 1.81 & 0.45 & 0.12 & b.d. & 0.21 & 0.28 \\
\hline $\mathrm{Pb}$ & 0.02 & b.d. & b.d. & 0.01 & 0.01 & 0.01 & 0.01 \\
\hline
\end{tabular}

As, Se, Bi, Hg - were below detection limits.
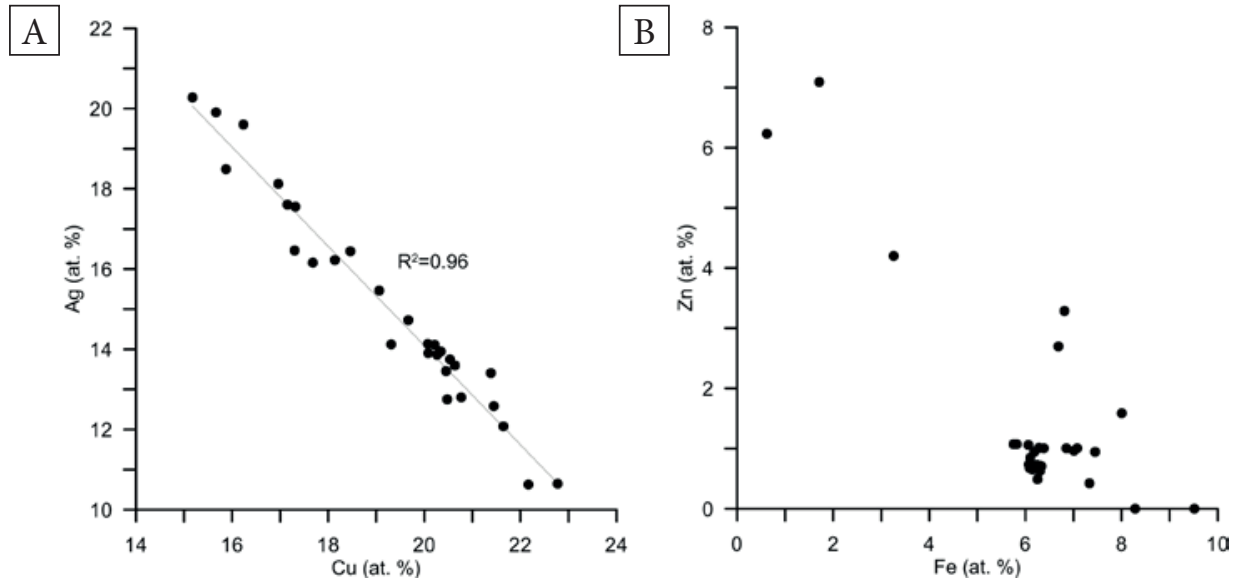

Fig. 4. Composition of high Ag-tetrahedrite from Ag-mineralization at the Stan Terg deposit: A) binary plot Ag vs. Cu (at. \%); B) binary plot $\mathrm{Zn}$ vs. Fe (at. \%)

Table 3

Chemical composition of native elements from the Ag-association at the Stan Terg deposit (at. \%); 1-4 electrum, 5-7 native antimony, b.d. - below detection limits, n.a. - not analyzed

\begin{tabular}{|l|c|c|c|c|c|c|c|}
\cline { 2 - 8 } \multicolumn{1}{c|}{} & 1 & 2 & 3 & 4 & 5 & 6 & 7 \\
\hline $\mathrm{Hg}$ & 0.18 & 0.11 & 0.08 & 0.23 & n.a. & n.a. & n.a. \\
\hline $\mathrm{Au}$ & 52.77 & 33.43 & 28.32 & 24.97 & n.a. & n.a. & n.a. \\
\hline $\mathrm{Ag}$ & 47.02 & 65.65 & 69.15 & 73.19 & 0.00 & 0.01 & 0.00 \\
\hline $\mathrm{Fe}$ & 0.03 & 0.64 & 0.74 & 0.00 & n.a. & n.a. & n.a. \\
\hline $\mathrm{Sb}$ & 0.00 & 0.17 & 1.75 & 1.60 & 99.29 & 99.25 & 98.77 \\
\hline $\mathrm{Pb}$ & n.a. & n.a. & n.a. & n.a. & 0.07 & 0.07 & 0.11 \\
\hline $\mathrm{Fe}$ & n.a. & n.a. & n.a. & n.a. & 0.51 & 0.54 & 0.97 \\
\hline $\mathrm{S}$ & n.a. & n.a. & n.a. & n.a. & 0.05 & 0.10 & 0.15 \\
\hline
\end{tabular}

As, $\mathrm{Bi}, \mathrm{Cu}$ - were below detection limits. 


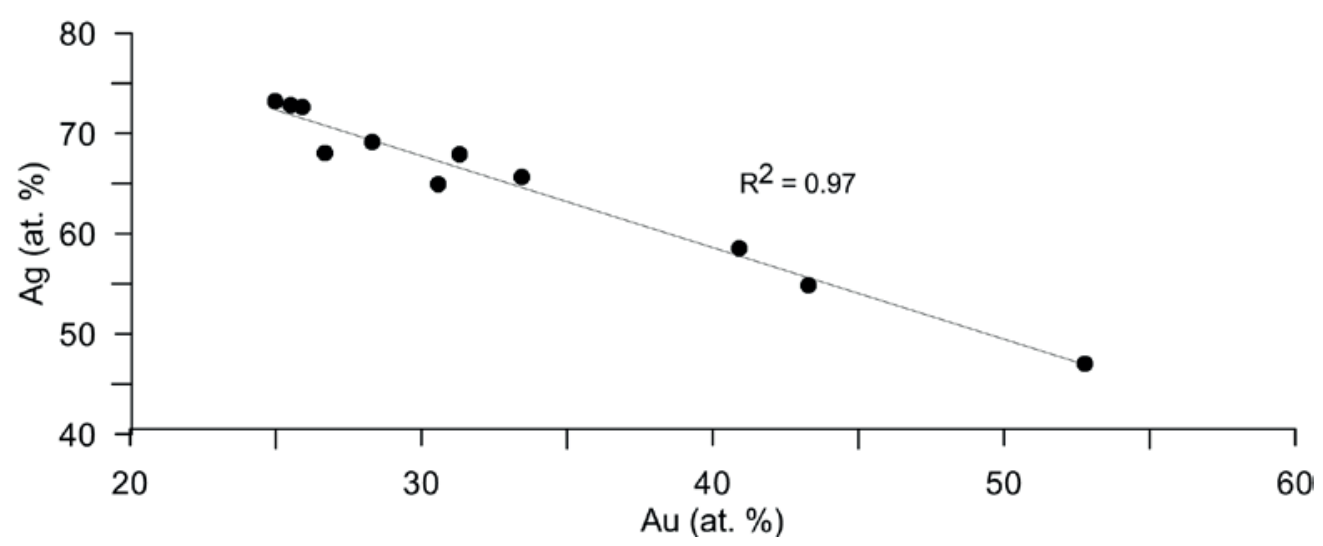

Fig. 5. Binary plot Ag vs. Au of electrum (at. \%) in the Ag-association in the Stan Terg deposit

A strong correlation between $\mathrm{Ag}$ and $\mathrm{Au}$ (Fig. 5) is observed, with $\mathrm{Ag}$ content between $47.02 \%$ and $73.19 \%$ (Au content $52.77 \%$ and $24.97 \%$, respectively).

Native antimony was found as a separate, irregular grain in a vugg of about $15 \mu \mathrm{m}$ size (Fig. $2 \mathrm{~F}$ ). Composition of the native $\mathrm{Sb}$ is presented in Table 3. The analyses indicated small Fe impurities; however they could be caused by the surrounding siderite.

\section{DISCUSSION}

This paper presents the electron microprobe (EPMA) geochemical results for pyrargyrite, pyrostilpnite, freieslebenite, Ag-rich tetrahedrite and freibergite. In the first stage of research, the authors carried out SEM-EDS analyses that additionally indicated the presence of stephanite and polybasite (Pršek et al. 2012). Unfortunately, due to the small size of crystals and difficult analytical conditions, we were not able to repeat these measurements by the means of the electron microprobe. Those analyses of stephanite indicated its elevated antimony content (2.4-2.5 apfu). The identified polybasite had an irregular form and occurred within chalcopyrite, together with Ag-bearing tetrahedrite and freibergite. The polybasite had a chemical composition with an increased content of copper (12\%) and a reduced content of silver (39\%) in comparison to the theoretical one.

\section{Epithermal character of Ag-mineralization}

The described mineral association is common in epithermal systems around the world. Similar associations occurring as tiny crystals in the fractures were described by Gemmell et al. (1989) from the Fresnillo district in Mexico. The mineral from Fresnillo has an increased As vs Sb and Se vs $S$ substitution, which indicated the additional presence of proustite and selenian polybasite. Lynch (1989) described the association of pyrargyrite, acantite, polybasite, stephanite, native Ag in the polymetallic veins form Yukon.

Pyrargyrite from Stan Terg has been assigned by Kepuska (1998) to the mesothermal phase of the hyrothermal stage of mineral precipitation in this deposit, whereas according to Topalovič (1971), pyrargyrite occurred in the epithermal stage together with jamesonite, antimonite, boulangerite, falkmanite, melnikovite, aragonite, calcite, dolomite, rhodochrosite and barite.

Ag-sulphosalts are believed to precipitate in low temperatures, late in the paragenetic sequence. Keighin \& Honea (1969) determined $197^{\circ} \mathrm{C}$ as the maximum temperature of stephanite formation. The mineral breaks down to pyrargyrite and argentite during heating above this temperature. Toulmin (1963) analyzed precipitation conditions of the pyrargyrite-proustite solid solution. They indicate it exists only up to $300^{\circ} \mathrm{C}$. Below this is a miscibility gap. Comparison to conditions of such association in the other deposits worldwide, may suggest that Ag-minerals in Stan Terg have precipitated in low temperatures from hydrothermal fluids, below $200^{\circ} \mathrm{C}$.

In the presented results, the content of silver in the electrum is relatively high, and it is around 48$74 \%$. The other generation of electrum found in the Stan Terg deposit has 12-17\% of Ag (authors' 
unpublished data). The gold dominant electrum was found in the skarn paragenesis, together with Bi-bearing minerals.

In comparison to most of the know epithermal mineralizations, Ag content in the described electrum is relatively high (Fig. 6). Comparing to the mineralogical composition of these occurrences, the high Ag content in electrum is usually related to a rhodochrosite-banded ore with predominant sulphides, such as pyrite, sphalerite, galena, chalcopyrite, tetrahedrite, Ag-minerals and stannite. Rhodochrosite from the Stan Terg has been characterized by Tomić (2003), where the assay of trace elements indicated the presence of Ag in this carbonate. We can assume that silver was transported and originated from the same hydrothermal solutions.

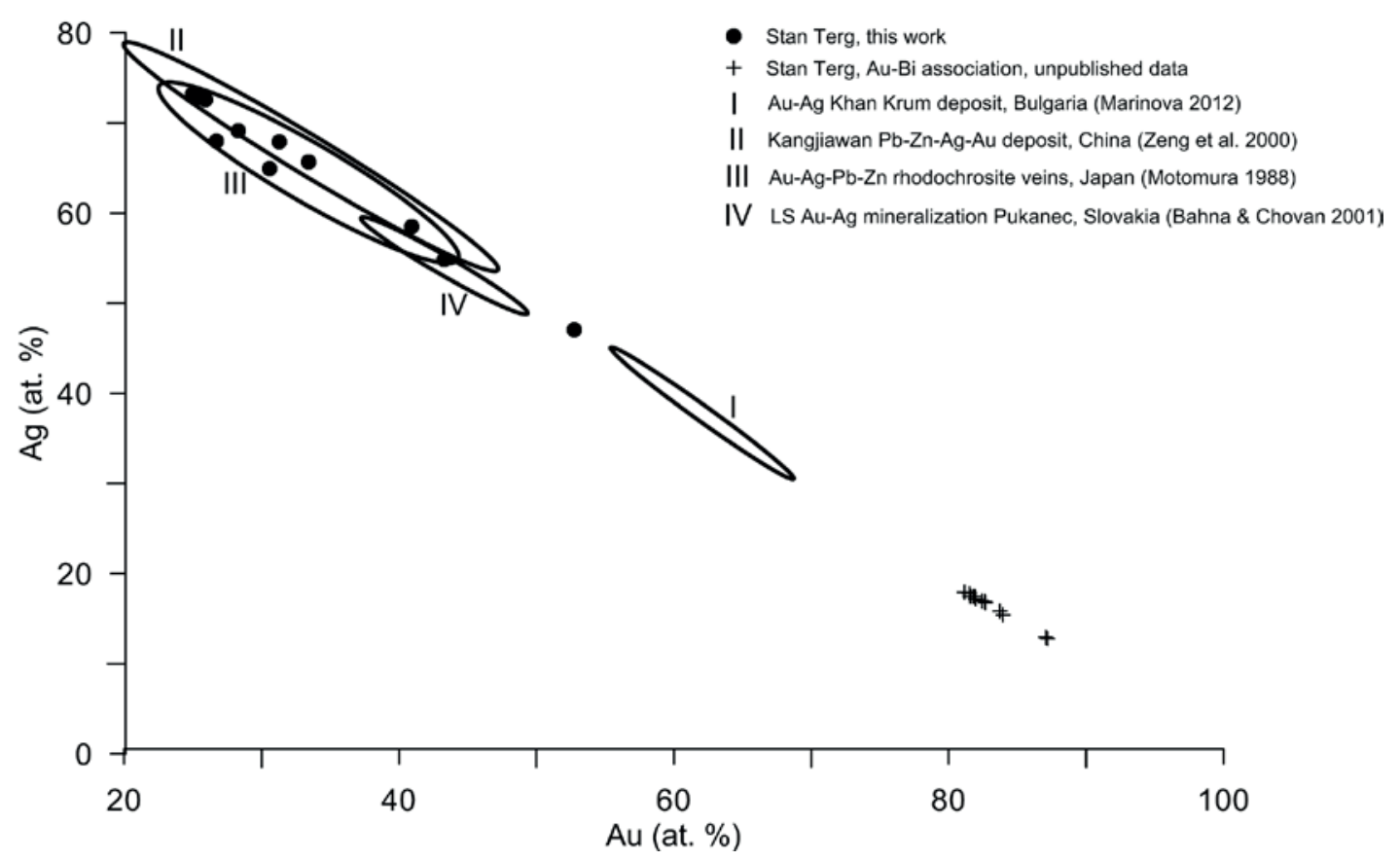

Fig. 6. Binary plot Ag vs. Au of electrum (at. \%) from Stan Terg and various epithermal systems

\section{Application in exploration}

Tetrahedrite may be of great interest in exploration. Wu \& Petersen (1977) noticed that silver content in tetrahedrite is increasing with distance from the center of volcanic activity in complex hydrothermal systems. They found Ag-content variations in a district scale in a vein, base metal system, in Casapalca, Peru. Lynch (1989) analyzed the tetrahedrite from the Keno Hill Ag- $\mathrm{Zn}-\mathrm{Pb}$ district in Yukon and had similar conclusions. In the external parts of this system, freibergite dominates over tetrahedite. Another epithermal mineral indicator is cinnabar, reported often together with Ag-mineralization (e.g. Cheilletz et al. 2002).
Stan Terg deposit is the largest known base metal deposit in northern Kosovo. Since the early $20^{\text {th }}$ century, it is well known that the deposit is surrounded by numerous different ore occurrences, such as Zijaqa, Melenica, Mazhiq, Rashan and Trstena (e.g. Tmava et al. 2003). These areas have been investigated by the Trepça Mining Company, but never excavated. The only signs of mining activity are ancient tunnels and shafts scattered over a wide area. The mineralization in this area has various characters (veins, stock work, replacement, disseminated) and is trapped in various litostratigraphic unites. Previous investigations in the Stan Terg area also indicated the presence of 
epithermal mineralization. Tiny cinnabar impregnations and stringers, mostly within the overlaying tuffs in the neighboring area, were reported by Titcom et al. (1936). Pyrargyrite was reported previously by Smejkal (1960) and Topalovič (1971), without any precise position.

The presence of freibergite and Ag-rich tetrahedrite in the northern, external part of Stan Terg, as well as previous reports of cinnabar presence in the vicinity could mean that besides medium temperature stages with base metals (main economic interest) and high temperature associations with $\mathrm{Bi}$ and $\mathrm{Au}$ (Kołodziejczyk et al. 2015), there is also an epithermal overprint in the external parts of the Stan Terg hydrothermal system, probably dominated by $\mathrm{Ag}-\mathrm{Au}-\mathrm{Sb} \pm \mathrm{Hg}$ mineralization.

\section{CONCLUSIONS}

1. Silver in the Stan Terg deposit occurs as a substitution in the lattice of galena, as well as in the form of its own minerals. The chemical composition of these phases has been confirmed with the use of an electron microprobe.

2. Paragenesis of silver minerals comprises pyrargyrite, pyrostilpnite, Ag-rich tetrahedrite, freibergite, freieslebenite, electrum and native antimony. These minerals occur within galena-dominated ore, with minor occurrences of pyrite, sphalerite and stannite. This kind of mineralization is surrounded by banded-rhodochrosite.

3. The Stan Terg deposit is a significant $\mathrm{Pb}-\mathrm{Zn}$ hydrothermal system, with high temperature parageneses, and low temperature phases, among which, Ag-bearing minerals have been recently found. The mode of Ag-association occurrence is following main ore deposition and indicates late precipitation. Comparing to other known data, the Ag-mineralization at the Stan Terg mine could occur at around $200^{\circ} \mathrm{C}$.

4. Similar geochemical zonality in the distribution of minor elements to hydrothermal systems formed elsewhere has been confirmed, and further exploration in the vicinity may lead to the discovery of new epithermal vein systems.
This work is part of the research program financed by the AGH University of Science and Technology statutory grant no. 11.11.140.320 and the Hugh E. McKinstry Fund of SEG.

\section{REFERENCES}

Bahna B. \& Chovan M., 2001. Low-sulfidation type of epithermal Au-Ag mineralization near Pukanec (Central Slovakia Neogene Volcanic fields). GeoLines, 13, $11-17$.

Berjaktarevic D., 1995. Polymetallic mineral phenomenon of Glama silver near by Gnjilane. [in:] Geologija i metalogenija Kopaonika, 19-22 jun 1995, Beograd, 326-333.

Cheilletz A., Levresse G., Gasquet D., Azizi-Samir M., Zyadi R., Archibald D.A. \& Farrar E., 2002. The giant Imiter silver deposit: Neoproterozoic epithermal mineralization in the Anti-Atlas, Morocco. Mineralium Deposita, $37,8,772-781$.

Dangić A., 1993. Tetriary lead-zinc ore deposits and calco-alcaline magmatism of the serbo-macedonian province: metallogenic and geochemical characteristics, hydrothermal systems and their evolution. Geološki anali Balkanskoga poluostrva (Annales géologiques de la péninsule Balkanique), 57, 1, 257-285.

Féraud J. \& Deschamps Y., 2009. French scientific cooperation 2007-2008 on the Trepça lead-zinc-silver mine and the gold potential of Novo Brdo/Artana tailings (Kosovo). BRGM Report No RP-57204-FR.

Gemmell J.B., Zantop H. \& Birnie R.W., 1989. Silver sulfosalts of the Santo Nino vein, Fresnillo District, Zacatecas, Mexico. Canadian Mineralogist, 27, 401-418.

Grossou-Valta M., Adam K., Constantinides D.C., Prevosteau J.M. \& Dimou E., 1990. Mineralogy of and potential beneficiation process for the Molai complex sulphide orebody, Greece. [in:] Gray P.M.J., Bowyer G.J., Castle J.F., Vaughan D.J. \& Warner N.A. (eds.), Sulphide deposits - their origin and processing, The Institution of Mining and Metallurgy, 119-133.

Höller W. \& Gandhi S.M., 1995. Silver bearing sulfoslats from the metamorphosed Rampura Agucha $\mathrm{Zn}-\mathrm{Pb}-(\mathrm{Ag})$ deposit, Rajasthhan, India. Canadian Mineralogist, 33, 1047-1057.

Hyseni S., Durmishaj B., Fetahaj B., Shala F., Berisha A. \& Large D., 2010. Trepça Ore Belt and Stan Terg mine geological overview and interpretation, Kosovo (SE Europe). Geologija, 53, 1, 87-92.

Keighin C.W. \& Honea R.M., 1969. The system Ag-Sb-S from $600^{\circ} \mathrm{C}$ to $200^{\circ} \mathrm{C}$. Mineralium Deposita, 4, 157-171.

Këpuska H., 1998. Distribumi i elementeve shpërndarëse dhe mikroelementeve përcjellëse ne mineralet kryesore xeheroformonjëse në vendburimi e plumb - zunkut “Trepça”. Universiteti i Prishinës, Fakulteti Xehetarisë Metalurgjisë [doctoral dissertation].

Kołodziejczyk J., 2012. Pb-Zn mineralization in Stan Terg deposit, Kosovo. Faculty of Geology, Geophysics and 
Environmental Protection, AGH University of Science and Technology, Cracow [MSc thesis, unpublished].

Kołodziejczyk J., Pršek J., Melfos V., Voudouris P.C., Maliqi F. \& Kozub-Budzyń G., 2015. Bismuth minerals from the Stan Terg deposit (Trepça, Kosovo). Neues Jahrbuch für Mineralogie. Abhandlungen, 192, 3, 317-333.

Lynch J.G., 1989. Large scale-hydrothermal zoning reflected in the tetrahedrite-freibergite solid solution, Keno Hill Ag-Pb-Zn district, Youkon. Canadian Mineralogist, 27, 383-400.

Marinova I., 2012. Composition of electrum from different styles of epithermal mineralization in the Au-Ag Khan Krum deposit, SE Bulgaria. [in:] National Conference with international participation "GEOSCIENCES 2012", Bulgarian Geological Society, Sofia, Bulgaria, 25-26

Moëlo Y., Makovicky E., Mozgova N., Jambor J.L., Cook N., Pring A., Paar W., Nickel E.H., Graeser S., Karup-Møller S., Balić-Žunić T., Mumme W., Vurro F., Topa D., Bindi L., Bente K. \& Shimizu M., 2008. Sulphosalts systematic: a review. Report of the sulphosalt sub-committee of the IMA Commission on Ore Mineralogy. European Journal of Mineralogy, 20, 1, 7-46.

Motomura M., 1988. Chemical composition of electrum from the Inakuraishi-type manganese deposits in southwestern Hokkaido, Japan. Mining Geology, 38, 211, 369373 [in Japan].

Pearson M.F., Clark K.F., Porter E.W. \& Gonzalez O., 1988. Mineralogy, fluid characteristics, and silver distribution at Real de Angeles, Zacatecas. Economic Geology, 83, 8, 1737-1759.

Pršek J., Kołodziejczyk J., Qela H., Asllani B. \& Mikuš T., 2012. Silver-bearing minerals at Stan TergPn-Zn Deposit, Republic of Kosovo. Acta Universitatis Szegediensis. Acta Mineralogica-Petrographica, Abstract Series, 7, 114.

Püttmann W., Fermont W.J.J. \& Speczik S., 1991. The possible role of organic matter in transport and accumulation of metals exemplified at the Permian Kupferschiefer formation. Ore Geology Reviews, 6, 6, 563-579.

Radosavljević S.A., Stojanović J.N., Radosavljević-Mihajlović A.S. \& Vuković N.S., 2016. (Pb-Sb)-bearing sphalerite from the Čumavići polymetallic ore deposit, Podrinje Metallogenic District, East Bosnia and Herzegovina. Ore Geology Reviews, 72, 253-268.

Rozhdestvenskaya I.V., Zayakina N.V. \& Samusikov V.P., 1993. Osobennosti kristallicheskoy struktury mineralov ryada tetraedrit - freybergit. Mineralogicheskiy Zhurnal, $15,2,9-17$.

Seifert T. \& Sandmann D., 2006. Mineralogy and geochemistry of indium-bearing polymetallic vein-type deposits: Implications for host minerals from the Freiberg district, Eastern Erzgebirge, Germany. Ore Geology Reviews, 28, 1, $1-31$.

Serafimovski T., Dolenec T. \& Tasev G., 2006. New data concerning the major ore minerals and sulphosalts from the
$\mathrm{Pb}-\mathrm{Zn}$ Zletovo Mine, Macedonia. RMZ - Materials and Geoenvironment, 52, 3, 535-548.

Shalaby I.M., Stumpfl E., Helmy H.M., El Mahallawi M.M. \& Kamel O.A., 2004. Silver and silver-bearing minerals at the Um Samiuki volcanogenic massive sulphide deposit, Eastern Desert, Egypt. Mineralium Deposita, 39, 5-6, 608-621.

Schalamuk I.B., Zubia M., Genini A. \& Fernández R.R., 1997. Jurassic epithermal Au-Ag deposits of Patagonia, Argentina. Ore Geology Reviews, 12, 3, 173-186.

Smejkal S., 1960. Strukture, mineralizacije, mineralne parageneze i geneza olovo cinkovih lezista kopaonicke oblasti. Rudarskogeoloski fakultet Univerziteta u Beogradu, Beograd [PhD thesis, unpublished].

Smejkal S. \& Rakić S., 1957. Mineralne parageneze olovno-cinkanih ruda lezista. Ajvalije, Prline i Kisnice. Vesnik ZGGI, 14, 7-28.

Strmić Palinkaš S., Palinkaš L.A., Renac C., Spangenberg J.E., Lüders V., Molnar M. \& Maliqi G., 2013. Metallogenic Model of the Trepča Pb-Zn-Ag Skarn Deposit, Kosovo: Evidence from Fluid Inclusions, Rare Earth Elements, and Stable Isotope Data. Economic Geology, 108, 135-162.

Taylor C.D., Lear K.G. \& Newkirk S.R., 1999. A Genetic Model for the Greens Creek Polymetallic Massive Sulfide Deposit, Admiralty Island, Southeastern Alaska. [in:] Cliff D.T. \& Craig A.J., Geology, Geochemistry, and Genesis of the Greens Creek Massive Sulfide Deposit, Admiralty Island, Southeastern Alaska, USGS Professional Paper No 1763, 419-429.

Titcomb H.A, Forgan Ch.B., Lerimer J. \& Page W.C., 1936. Trepça Mines Limited. Mining and Metallurgy, 17, 9, 424-426; 17, 10, 481-484; 17, 11, 514-518 and 527; 17, 12, 584-585.

Tmava A. \& Koliqi A., 2003. Veçori te mineralizimit polimetalor ne vendburimin "Melenica", Kosove. Buletini i Shkencave Gjeologjike, 2, 26-31.

Tomić Z., 2003. Ferruginous rhodochrosite from the deposit Stari Trg-Trepča (Serbia). Bulletin Geologie, Hydrogeologie, et Geologie d'Ingenieur, 53, 225-238.

Topalovič A., 1971. Metalogenija područja “Trepča”. Rudarsko Geološki Fakultet, Univerziteta u Beogradu [PhD thesis, unpublished].

Toumlin P., 1963. Proustite-pyrargyrite solid solutions. American Mineralogist, 48, 725-736.

Uytenbogaardt W. \& Burke E.A.J., 1971. Tables for microscopic identification of ore minerals. Elsevier Publishing Company, Amsterdam, London, New York.

Wu I. \& Petersen U., 1977. Geochemistry of tetrahedrite and mineral zoning at Casapalca, Peru. Economic Geology, 72, 993-1016.

Zeng N., Izawa E., Motomura Y. \& Lai L., 2000. Silver minerals and paragenesis in the Kangjiawan $\mathrm{Pb}-\mathrm{Zn}-\mathrm{Ag}-$ $\mathrm{Au}$ deposit of the Shuikoushan mineral district, Hunan Province, China. Canadian Mineralogist, 38, 1, 11-22. 